\title{
PENGARUH METODE BRAINSTORMING TERHADAP MENULIS PERSUASIFSISWAKELAS VIII SMPN 15 SUKABUMI
}

\author{
Anisa Firdaus $^{1}$, Hera Wahdah Humaira ${ }^{2}$, Asep Firdaus ${ }^{3}$ \\ Universitas Muhammadiyah Sukabumi \\ Jl. R. Syamsudin, S.H. No.50. Telepon(0266) 218342 \\ Pendidikan Bahasa dan Sastra Indonesia, Fakultas Keguruan dan Ilmu Pendidikan, \\ Kota Sukabumi \\ anisafirdaus89@gmail.com
}

\begin{abstract}
Abstrak
Penelitian ini bertujuan untuk mengetahui peningkatan kemampuan menulis teks persuasif siswa kelas VIII SMP Negeri 15 Kota Sukabumi dengan menggunakan metode Brainstorming. Penerapan metode Braintorming dilakukan agar siswa berpartisipasi aktif selama proses pembelajaran dengan mengumpulkan ide, pendapat atau gagasan siswa sebanyak mungkin tanpa dinilai benar atau salah. Penelitian ini menggunakan metode kuantitatif pra eksperimental dengan uji-t. Sampel berjumlah 38 siswa dengan desain penelitian one group pretest posttest design.Data yang diperoleh adalahnilai hasil pretest dan posttest melalui tes tulisan dan observasi. Juga dengan mencari nilai $\Sigma \mathrm{d}$ dan $\Sigma \mathrm{d}^{2}$. Nilai hasil pretest yang diperoleh siswa rata-rata $55,52 \%$ dapat dikatakan masih kurang. Namun setelah diberi treatment, yaitu metode Brainstorming nilai hasil posttest siswa rata-rata $87,23 \%$. Mengalami peningkatan sebesar $31,71 \%$. Berdasarkan uji statistik, nilai $t_{\text {hitung }}$ sebesar 13,90 sedangkan nilai $t_{\text {tabel }}$ sebesar 2,042. Dengan demikian dapat dikatakan bahwa $t_{\text {hitung }}>t_{\text {tabel }}$ atau hipotesis diterima $\left(\mathrm{H}_{1}\right)$, artinya metode Brainstorming berpengaruh terhadap kemampuan menulis teks persuasif siswa kelas VIII SMP Negeri 15 Kota Sukabumi tahun ajaran 2018/2019.
\end{abstract}

Kata Kunci:pengaruh,brainstorming, menulis persuasif

\section{PENDAHULUAN}

Bahasa merupakan aspek penting yang digunakan dalam lingkungan pendidikan khususnya kegiatan belajar mengajar agar tercapainya sasaran atau tujuan pembelajaran. Pembelajaran bahasa Indonesia di sekolah pada umumnya berfungsi untuk mengajarkan siswa dalam hal berbahasa. Sehubungan dengan hal itu, di sekolah siswa tidak hanya belajar pengetahuan bahasa saja, juga belajar bahasa sebagai alat komunikasi baik secara lisan maupun tulis. Namun, pada umumnya pengguna bahasa lebih terampil menggunakan bahasa secara lisan dibanding tulisan karena lisan dianggap lebih mudah. Oleh karena itu, 
keterampilan berbahasa perlu diarahkan agar kemampuan bahasa lisan dan bahasa tulis siswa menjadi seimbang.

Sekolah sebagai sarana pencerdas anak bangsa pada umumnya harus mampu mencetak siswa yang unggul dalam berbagai bidang, khususnya menulis. Sebagai peserta didik, dalam hal menulis siswa dituntut mampu menguasai berbagai aspek seperti menulis karangan atau paragraf, khususnya menulis paragraf persuasif. Dalam menulis paragraf ini siswa dituntut pandai dalam pemilihan kata dan penyusunan kalimat, mampu menentukan ide, menguasai struktur setiap paragraf, dan menggunakan kaidah kebahasaan yang tepat dan sesuai dengan yang telah diajarkan di sekolah.Namun pada kenyataanya banyak siswa menghadapi masalah diantaranya kesulitan dalam menentukan ide tulisan, penggunaan bahasa, dan biasnya perbedaan antara paragraf persuasif dengan paragraf lain.Terlebih siswa belum mampu menyajikan teks persuasif yang sesuai dengan struktur dan kaidah kebahasaan.

Salah satu penyebab rendahnya kemampuan siswa dalam menulis adalah karena kurangnya penggunaan metode pembelajaran. Faktanya di kelas guru lebih sering menggunakan metode ceramah. Pemilihan metode pembelajaran sangat berpengaruh terhadap proses belajar mengajar. Metode yang tepat akan menghasilkan pembelajaran yang efektif dan tercapainya tujuan pembelajaran. Pemilihan metode pembelajaran dapat disesuaikan dengan materi yang akan dipelajari. Oleh karena itu, berdasarkan kendala di atas perlu digunakan suatu metode pembelajaran yang dimungkinkan efektif untuk materi pembelajaran menulis agar siswa dapat berperan aktif dalam proses belajar.Salah satu metode yang memungkinkan siswa untuk bisa mengembangkan dan melatih kemampuan menulis yaitu dengan metode pembelajaranBrainstorming.

Penelitian serupa pernah dilakukan oleh Rangga Tina, Erizal Gani, dan Nursaid (2013) berjudul Peningkatan Pembelajaran Menulis Argumentasi melalui Model Pembelajaran Brainstorming. Dalam Penelitiannya, dinyatakan penerapan model Brainstormingdapat meningkatkan proses dan hasil pembelajaran menulis karangan argumentasi siswa kelas X.1 SMA Negeri 2 Tebo, Jambi. Hal ini terlihat dari meningkatnya persentase kemampuan siswa mencapai 23,01\%.Penelitian lain dilakukan oleh Mui'in, A., dkk (2018) berjudul Peningkatan Keterampilan Menulis Teks Persuasi Menggunakan Strategi Menulis Terbimbing dan Pendekatan Pembelajaran Kontekstual. Dalam penelitian tersebut mengungkapkan bahwa kemampuan menulis teks persuasi masih rendah yaitu di bawah KKM sehingga dibutuhkan sebuah strategi dan pendekatan sebagai upaya untuk meningkatkan kemampuan menulis teks persuasi siswa.Berdasarkan penelitian tersebut, peneliti terinspirasi untuk melakukan penelitian serupa dengan variabel yang berbeda. Karena 
itu peneliti memilih judul "Pengaruh Metode Pembelajaran Brainstorming terhadap Kemampuan Menulis Teks Persuasif Siswa Kelas VIII SMP Negeri 15 Kota Sukabumi Tahun Ajaran 2018/2019”.

\section{KAJIAN TEORI}

\section{Menulis}

Menulis adalah aktivitas aktif produktif, yaitu aktivitas yang menghasilkan sebuah bahasa dalam bentuk berbeda. Menulis dapat dianggap sebagai suatu proses maupun suatu hasil. Menulis merupakan kegiatan yang dilakukan oleh seseorang untuk menghasilkan sebuah tulisan (Nurgiyantoro, 2009: 273).Fungsi menulis dikemukakan oleh bebeerapa ahli, salah satunya Hendriyanto \& Nimas (2014: 93) mengungkapkan bahwa menulis berfungsi sebagai alat komunikasi dalam bentuk tulis dan bisa digunakan sebagai sarana komunikasi secara tidak langsung. Menulis memiliki manfaat beragam seperti yang diungkapkan oleh Akhadiah (dalam Wicaksono, 2014: 29) bahwa salah satu hal yang mendasari alasan mengapa menulis perlu diajarkan adalah karena menulis memiliki banyak manfaat. Diantaranya menulis dapat menambah wawasan seseorang mengenai suatu isu atau topik karena penulis mencari sumber informasi tentang topik yang akan ditulisnya. Menulis juga dapat memperjelas sesuatu kepada diri penulis karena gagasan-gagasan yang semula masih berserakan dan tidak runtut di dalam pikiran, dapat dituangkan secara runtut dan sistematis dalam sebuah tulisan.

\section{Teks Persuasif}

Pengertian mengenai teks persuasif dipaparkan oleh beberapa ahli seperti Hikmat dan Solihati (2013: 68) berpendapat bahwa persuasif merupakan paragraf yang mengajak, membujuk, memengaruhi pembaca atau khalayak agar melakukan sesuatu sesuai arahan penulis. Paragraf persuasif biasanya digunakan dalam dunia politik, pendidikan, periklanan, dan dunia propaganda.

Teks persuasif memiliki struktur agar teks tersebut dapat ditulis dengan sistemtis dan terarah. Kosasih (2017: 186) mengemukakan struktur teks persuasif diantaranya 1) pengenalan isu, yakni berupa pengantar atau penyampaian tentang suatu masalah yang menjadi dasar sebuah tulisan atau pembicaraan. 2) rangkaian argumen, yakni sejumlah pendapat penulis disertai fakta singkat untuk memperkuat argumen. 3) pernyataan ajakan, yakni sebagai inti dari teks persuasif. Dalam teks dimasukkan kata-kata atau kalimat ajakan 
baik tersurat maupun tersirat untuk memengaruhi pembaca atau pendengar agar melakukan sesuatu. 4) Penegasan kembali, yakni penegasan atas pernyataan-pernyataan sebelumnya. Pada bagian ini ditandai dengan ungkapan-ungkapan seperti dengan demikian, oleh karena itu,dan sebagainya.

Kosasih menambahkan, kaidah kebahasaan teks persuasif yaitu:1) ditandai dengan kata-kata harus, penting, hendaknya, sebaiknya, usahakanlah, jangan, hindarilah, sepantasnya, waspadalah, dan kata kerja imperatif jadikanlah. 2) menggunakan kata-kata teknis atau peristilahan yang berkenaan dengan topik yang dibahas. 3) menggunakan konjungsi kausalitas atau bisa juga disebut sebagai kata hubung yang argumentatif. Misalnya jika, sebab, karena, dengan demikian, akibatnya, oleh karena itu. 4) menggunakan kata kerja mental, seperti diharapkan, memprihatinkan, menyimpulkan, dan sebagainya. 5) Ada pula yang menggunakan kata perujukan, seperti berdasarkan data...., merujuk pada pendapat...., pernyataan-pernyataan tersebut digunakan untuk lebih meyakinkan dan memperkuat bujukan.

Penelitian akan lebih terarah apabila terdapat langkah-langkah penelitian. Untuk itu dikemukakan langkah-langkah menulis teks pesuasif menurut Juhara, Eriyandi \& Rita (2010: 59) diantaranya (a) menentukan topik paragraf, (b) menyusun kerangka paragraf yang terdiri atas gagasan utama dan gagasan pendukung. Jika kerangka paragraf telah dibuat, kemudian (c) susunlah paragraf persuasif sesuai kerangka.

\section{Metode Brainstorming}

Brainstorming adalah metode pembelajaran kelompok yang peserta didiknya memiliki latar belakang pengetahuan dan pengalaman yang berbeda-beda untuk menghimpun gagasan dan pendapat dalam rangka menemukan atau memilih berbagai pernyataan sebagai jawaban terhadap pertanyaan yang berkaitan dengan kebutuhan belajar, sumber-sumber, hambatan, dan lain sebagainya (Sudjana, 2010:74).Melalui pembelajaran brainstorming, peserta didik dapat memiliki kemampuan dan keterampilan untukmemaparkan ide yang berhubungan dengan area topik yang dibahas, mengembangkan kreativitas berpikir, dan menemukan solusi terhadap masalah yang dihadapi (Wicaksono \& Ahmad, 2016: 270).

Agar penelitian lebih terarah,maka dikemukakan langkah-langkah pembelajaranbrainstorming menurut Roestiyah (dalam Dewi, 2014: 14) yaitu pemberian informasi dan motivasi, identifikasi, klasifikasi, verifikasi dan konklusi. Lebih spesifik, Yaumi (2012: 45) mengemukakan langkah-langkah brainstorming diantaranya 1) guru menentukan topik pembahasan yang memerlukan aktivitas sumbang saran. 2) guru meminta setiap siswa mengemukakan ide yang berhubungan dengan komponen-komponen judul, 
subjudul, atau bagian-bagian yang lebih kecil dari itu. 3) guru mencatat atau mengetik setiap kata atau kalimat yang dipaparkan oleh masing-masing siswa. 4) guru membuat kategori, menggabungkan, atau memperbaiki kemungkinan adanya kesalahan kata. 5) secara bersamasama guru dan siswa menganalisis efek atau hasil. 6) prioritaskan pilihan/susun daftar kata yang sesuai. 7) menyimpulkan dan menentukan aktivitas tindak lanjut.

\section{METODE PENELITIAN}

Penelitian ini menggunakan metode kuantitatif pra eksperimental. Waktu penelitian tanggal 29 April sampai 1 Mei 2019. Objek penelitian yaitu kelas VIII A SMP Negeri 15 Kota Sukabumi dengan sampel 38 siswa. Penetapan sampel berdasarkan tekniksimple random samping.Desain penelitian yaitu one group pretest posttest design. Prosedur penelitian diawali dari tahap persiapan, tahap pelaksanaan, dan tahap pengolahan. Instrumen penelitian yaitu nilai pretest dan posttest siswa melalui tes tulisan dan observasi. Hasil test tersebut dinilai berdasarkan struktur dan kaidah kebahasaan teks persuasif dengan pemberian skor 4 sangat baik, skor 3 cukup baik, skor 2 kurang baik, skor 1 tidak baik.Tahapan analisis data yaitu pemberian tes, pemberian skor, lalu mengubah skor ke dalam bentuk nilai dengan cara skor mentah dikali 100 dibagi skor maksimal.

Setelah semua data terkumpul, selanjutnya digunakan rumus uji-t dengan mencari mean, selisih atau gain $(d)$ dan gain $\operatorname{kuadrat}\left(d^{2}\right)$, standar deviasi, serta uji hipotesis untuk mengetahui hipotesis diterima atau ditolak.

\section{HASIL PENELITIAN DAN PEMBAHASAN}

\section{Kemampuan Menulis Teks Persuasif Siswa Sebelum Menggunakan Metode Brainstorming}

Pelaksanaan pembelajaran dilakukan tiga kali yaitu pretest (sebelum diberi perlakuan), treatment (perlakuan), dan posttest (setelah diberi perlakuan). Agar dapat mengetahui pengaruh penggunaan metode Brainstorming, langkah pertama adalah dengan memberikan test awal atau pretest pada siswa. Kegiatan pembelajaran diawali dengan guru atau peneliti mengucapkan salam, siswa memimpin doa, peneliti mengabsen kehadiran siswa, menyampaikan tujuan pembelajaran, memotivasi siswa, kemudianpeneliti dan siswa menyepakati kegiatan yang akan dilaksanakan. Setelah kegiatan awal, selanjutnya adalah 
kegiatan inti. Peneliti memberikan pertanyaan pada siswa mengenai teks persuasif untuk mengetahui kemampuan siswa, selanjutnya peneliti memberitahukan kriteria penilaian, kemudian siswa diberikan tugas untuk menulis teks persuasif dengan tema bebas. Setelah selesai siswa mengumpulkan hasil kerjanya, peneliti memberikan kesempatan kepada siswa untuk bertanya mengenai pembelajaran, peneliti memberikan evaluasi selanjutnya menyimpulkan pembelajaran bersama dengan siswa.

Berdasarkan penelitian yang dilakukan dengan langkah-langkah tersebut, peneliti mendapatkan data dari test menulis teks persuasif siswa. Data ini sebagai perbandingan untuk mengetahui pengaruhnya sebelum menggunakan metode dengan sesudah meggunakan metode. Berikut ini adalah nilai pretest siswa kelas VIII A.

Tabel 1 Hasil Pretest

\begin{tabular}{|c|c|c|c|c|c|}
\hline Kode Siswa & $\begin{array}{c}\text { Nilai } \\
\text { Pretest }\end{array}$ & Kode Siswa & $\begin{array}{c}\text { Nilai } \\
\text { Pretest }\end{array}$ & Kode Siswa & $\begin{array}{c}\text { Nilai } \\
\text { Pretest }\end{array}$ \\
\hline 1718.7 .001 & 35 & 1718.7 .014 & 50 & 1718.7 .027 & 65 \\
\hline 1718.7 .002 & 60 & 1718.7 .015 & 60 & 1718.7 .028 & 30 \\
\hline 1718.7 .003 & 65 & 1718.7 .016 & 65 & 1718.7 .029 & 40 \\
\hline 1718.7 .004 & 55 & 1718.7 .017 & 60 & 1718.7 .030 & 60 \\
\hline 1718.7 .005 & 55 & 1718.7 .018 & 35 & 1718.7 .031 & 65 \\
\hline 1718.7 .006 & 55 & 1718.7 .019 & 30 & 1718.7 .032 & 75 \\
\hline 1718.7 .007 & 60 & 1718.7 .020 & 75 & 1718.7 .033 & 55 \\
\hline 1718.7 .008 & 50 & 1718.7 .021 & 60 & 1718.7 .034 & 70 \\
\hline 1718.7 .009 & 80 & 1718.7 .022 & 60 & 1718.7 .035 & 60 \\
\hline 1718.7 .010 & 70 & 1718.7 .023 & 65 & 1718.7 .036 & 65 \\
\hline 1718.7 .011 & 60 & 1718.7 .024 & 50 & 1718.7 .037 & 40 \\
\hline 1718.7 .012 & 70 & 1718.7 .025 & 25 & 1718.7 .038 & 35 \\
\hline 1718.7 .013 & 35 & 1718.7 .026 & 65 & & \\
\hline Jumlah & & & $\mathbf{2 1 1 0}$ & & \\
\hline Rata-rata & & & $\mathbf{5 5 , 5 2}$ & & \\
\hline
\end{tabular}

Berdasarkan penelitian yang dilakukan pada kelas VIII SMP negeri 15 Kota Sukabum itahun pelajaran 2018/2019, di dapat nilai hasil pretest. Data ini digunakan untuk mengukur kemampuan menulis teks persuasive siswa sebelum diberikan treatment. Dari sampel penelitian sebanyak 38 siswa, didapat nilai pretest dengan rata-rata 55,52. Nilai terkecil terdapat pada no urut 25 dengan perolehan nilai 25 , dan nilai terbesar terdapat pada no urut 09 dengan perolehan nilai 80 . 
Berdasarkan data pretest dapat dikatakan bahwa kemampuan siswa belum maksimal. Hanya satu siswa yang mencapai Kriteria Ketuntasan Minimal (KKM). Masih banyak siswa yang belum mampu menulis teks persuasive sesuai dengan struktur dan kaidah kebahasaan yang baik dan benar. Sebagian besar dari siswa tidak menuliskan pengenalan isu, rangkaian argument belum tepat dan tidak disertai fakta, pernyataan ajakan masih tertukar dengan penegasan kembali, dan belum memahami penggunaan kaidah kebahasan teks persuasive dengan benar.

\section{Kemampuan Menulis Teks Persuasif Siswa Setelah Menggunakan Metode Brainstorming}

Setelah memberikan pretest, langkah selanjutnya adalah treatment dan posttest. Treatment dalam pembelajaran dilakukan dengan menggunakan metode Brainstorming. Kemudian siswa diberikan test akhir atau posttest dengan maksud untuk mengetahui kemampuan menulis teks persuasif siswa setelah diberi perlakuan. Berikut ini adalah langkah-langkah treatmen dan posttest.

\section{a. Kegiatan Treatment}

Kegiatan inti pembelajaran dengan menggunakan treatmentdiantaranya peneliti menciptakan suasana yang menyenangkan untuk membangkitkan semangat belajar siswa, kemudian siswa duduk berdasarkan kelompoknya, peneliti menyampaikan materi teks persuasif dan memberikan kesempatan pada siswa untuk membaca materi, peneliti memberikan topik atau tema yang berbeda-beda kepada setiap kelompok, siswa diajak untuk memberikan sumbang saran pemikiran sebanyak-banyaknya mengenai topik atau tema yang telah ditentukan, kemudian siswa mengklasifikasikan ide-ide yang terkumpul berdasarkan kategori struktur dan kaidah kebahasaan teks persuasif, peneliti bersama siswa menganalisis efek atau hasil dari klasifikasi ide-ide dan menyimpulkan semua ide-ide yang relevan. Setelah ide-ide relevan telah selesai diklasifikasikan, selanjutnya siswa menulis teks persuasif secara utuh berdasarkan klasifikasi atau kategori yang telah disusun.

\section{b. Kegiatan Posttest}

Setelah melakukan pembelajaran dengan menggunakan metode brainstorming, selanjutnya dilakukan tes akhir atau posttest untuk mengetahui peningkatan kemampuan siswa setelah diberi treatment atau perlakuan. Kegiatan inti pembelajaran diantaranya peneliti memberikan pertanyaan pada siswa mengenai teks persuasif untuk mengetahui kemampuan 
siswa, peneliti memberitahukan kriteria penilaian, siswa diberikan tugas untuk menulis teks persuasif dengan tema bebas. Setelah selesai kemudian lembar hasil kerja siswa dikumpulkan.

Berdasarkan langkah-langkah di atas, dapat dilihat bahwa pertemuan kedua pembelajaran adalah treatment dengan menggunakan metode Brainstorming, selanjutnya pertemuan ketiga adalah posttest dengan maksud untuk mengetahui kemampuan menulis teks persuasif siswa setelah menggunakan metode Brainstorming. Hasil posttest siswa kelas VIII A SMPN 15 Kota Sukabumi dapat dilihat pada tabel berikut ini.

Tabel 2 Hasil Nilai Posttest

\begin{tabular}{|c|c|c|c|c|c|}
\hline Kode Siswa & $\begin{array}{c}\text { Nilai } \\
\text { Posttest }\end{array}$ & Kode Siswa & $\begin{array}{c}\text { Nilai } \\
\text { Posttest }\end{array}$ & Kode Siswa & $\begin{array}{c}\text { Nilai } \\
\text { Posttest }\end{array}$ \\
\hline 1718.7 .001 & 85 & 1718.7 .014 & 80 & 1718.7 .027 & 85 \\
\hline 1718.7 .002 & 85 & 1718.7 .015 & 80 & 1718.7 .028 & 85 \\
\hline 1718.7 .003 & 80 & 1718.7 .016 & 80 & 1718.7 .029 & 90 \\
\hline 1718.7 .004 & 80 & 1718.7 .017 & 95 & 1718.7 .030 & 95 \\
\hline 1718.7 .005 & 95 & 1718.7 .018 & 90 & 1718.7 .031 & 90 \\
\hline 1718.7 .006 & 90 & 1718.7 .019 & 85 & 1718.7 .032 & 90 \\
\hline 1718.7 .007 & 80 & 1718.7 .020 & 95 & 1718.7 .033 & 90 \\
\hline 1718.7 .008 & 90 & 1718.7 .021 & 80 & 1718.7 .034 & 90 \\
\hline 1718.7 .009 & 95 & 1718.7 .022 & 100 & 1718.7 .035 & 90 \\
\hline 1718.7 .010 & 90 & 1718.7 .023 & 85 & 1718.7 .036 & 85 \\
\hline 1718.7 .011 & 85 & 1718.7 .024 & 80 & 1718.7 .037 & 85 \\
\hline 1718.7 .012 & 90 & 1718.7 .025 & 90 & 1718.7 .038 & 80 \\
\hline 1718.7 .013 & 90 & 1718.7 .026 & 85 & & \\
\hline Jumlah & & $\mathbf{3 3 1 5}$ & \\
\hline Rata-rata & & $\mathbf{8 7 , 2 3}$ & \\
\hline
\end{tabular}

Berdasarkan hasil data posttest di atas, dapat dilihat bahwa setelah menggunakan metode Brainstormingnilai siswa berada pada kisaran 80 sampai 100. Jumlah nilai postest siswa 3315 dengan rata-rata 87,23. Berdasarkan perolehan nilai pada tabel di atas, kemampuan siswa dalam menulis teks persuasif berdasarkan struktur dan kaidah kebahasaan teks sudah maksimal. Siswa sudah mampu menuliskan pengenalan isu dengan tepat, menuliskan rangkaian argumen dengan fakta yang jelas, memahami pernyataan ajakan, menuliskan penegasan kembali dengan benar, dan menggunakan kaidah kebahasaan teks persuasif dengan baik. Meskipunadabeberapasiswa yang belummaksimal di beberapaaspek, 
namunsecarakeselurahansetiapsiswasudahmendapatnilai di atas KKM.Nilai posttest siswa meningkat atau lebih baik dibandingkan dengan nilai pretest.

\section{Pengaruh Penggunaan Metode Brainstorming terhadap Kemampuan Menulis Teks Persuasif Siswa}

Pengaruh penggunaan metode brainstorming dapat dilihat dari perhitungan data dengan rumus. Sebelum menghitung akumulasi data secara keseluruhan, langkah pertama adalah dengan mencari selisih atau gain $(d)$ dan gain kuadrat $\left(d^{2}\right)$. Gain diperlukan untuk mengetahui perbedaan antara nilai pretest dengan nilai posttest. Berikut ini adalah selisih hasil pretest dan posttest siswa kelas VIII A SMPN 15 Kota Sukabumi.

Tabel 3 Perbedaan hasil pretest dan posttest

\begin{tabular}{|c|c|c|}
\hline Nilai Pretest & Nilai Posttest & Gain $(\boldsymbol{d})$ \\
\hline 55,52 & 87,23 & 31,71 \\
\hline
\end{tabular}

Berdasarkan tabel di atas, dapat dilihat bahwa setelah menggunakan metode Brainstorming, nilai posttest siswa mengalami peningkatan sebesar 31,71. Aspek penilaian yaitu berdasarkan struktur dan kaidah kebahasaan teks persuasif. Salah satu aspek yang dinilai yaitu pengenalan isu. Pada saat pretest, rata-rata nilai siswa pada aspek ini 1,76, pada postest meningkat menjadi 3,47. Hal tersebut menunjukkan bahwa siswa mampu menulis teks persuasif menggunakan pengenalan isu yang baik. Kemudian aspek rangkaian argumen dari 2,55 menjadi 3,31 maka dapat dikatakan bahwa siswa mampu menuliskan rangkaian argumen dengan jelas disertai fakta yang relevan. Selain itu, aspek pernyataan ajakan dari 1,63 menjadi 3,68. Siswa mampu menuliskan pernyataan ajakan teks persuasif dengan benar dan tidak terbalik dengan aspek penegasan kembali seperti pada saat pretest. Untuk aspek penegasan kembali dari 2,60 menjadi 3,87 menunjukkan bahwa siswa sudah baik dalam menuliskan teks persuasif pada aspek ini. Terakhir yaitu kaidah kebahasaan dari 2,55 menjadi 3,10. Dengan demikian siswa sudah memahami kaidah kebahasaan teks persuasif dan dapat mengaplikasikannya ke dalam teks yang ditulisnya.

Berdasarkan hasil analisis data menggunakan statistik, terlihat bahwa posttest mengalam ipeningkatan yang signifikan. Setelah menggunakan metode Brainstorming 
kemampuan siswa dalam menulis teks persuasive meningkat sebesar 31,71. Terlihat dari perolehan nilai pretest 2110 dengan rata-rata 55,52 sedangkan jumlah posttest 3315 dengan rata-rata 87,23.Berdasarkan hasil hitungan dengan uji-t signifikan, didapat hasil $t_{\text {hitung }}$ sebesar

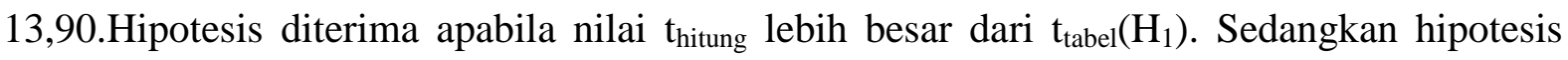
ditolak apabila $t_{\text {hitung }}$ lebih kecil dari $\mathrm{t}_{\text {tabel }}\left(\mathrm{H}_{0}\right)$. Berdasarkan hasil penghitungan di atas dapat dilihat bahwa nilai posttest mengalami peningkatan dibandingkan dengan nilai pretest. Nilai $t_{\text {hitung }} 13,90$ dikonsultasikan dengan $t_{\text {tabel }}$ pada drajat kebebasan $n-1$ dan taraf signifikansi $\alpha$ 5\% maka nilai $\mathrm{t}_{\text {tabel }}$ yaitu 2,042. Berdasarkan nilai tersebut dapat dilihat bahwa $\mathrm{t}_{\text {hitung }}>\mathrm{t}_{\text {tabel }}$. Dengan demikian dapat diartikan bahwa hipotesis diterima karena terdapat signifikansi antara uji pretest dengan posttest. Atau dengan kata lain brainstorming berpengaruh terhadap kemampuan menulis teks persuasif siswa kelas VIII SMP Negeri 15 Kota Sukabumi tahun ajaran 2018/2019.

\section{SIMPULAN}

Berdasarkan penelitian pengaruh metode Brainstorming terhadap kemampuan menulis teks persuasif siswa kelas VIII SMP Negeri 15 Kota Sukabumi tahun pelajaran 2018/2019, dapat disimpulkan bahwa. Pertama, kemampuan menulis teks persuasif siswa saat pretest secara keseluruhan dapat dikatakan masih kurang karena terlihat dari jumlah nilai pretest sebesar 2110 dengan rata-rata 55,52.Kedua, kemampuan menulis teks persuasif siswa setelah mendapat treatment dengan metode Brainstorming mengalami peningkatan. Terlihat dari jumlah nilai posttest sebesar 3315 dengan rata-rata 87,23. Ketiga, metode Brainstorming berpengaruh terhadap kemampuan menulis teks persuasif siswa kelas VIII SMP Negeri 15 Kota Sukabumi. Terlihat dari rata-rata nilai pretest 55,52 dan rata-rata nilai posttest 87,27 mengalami peningkatan sebesar 1205 dengan rata-rata 31,71. Berdasarkan uji hipotesis yang dilakukan sebelumnya, hasil $t_{\text {hitung }}(13,90)$ lebih besar dari $t_{\text {tabel }}(2.042)$. Dengan demikian dapat disimpulkan bahwa hipotesis diterima, atau metode Brainstorming berpengaruh terhadap kemampuan menulis teks persuasif siswa kelas VIII SMP Negeri 15 Kota Sukabumi tahun pelajaran 2018/2019. 


\section{SARAN}

Berdasarkan simpulan di atas, setelah dikenalkannya metode Brainstorming ini diharapkan siswa lebih meningkatkan keaktifan, keikutsertaan, dan mengembangkan ideidenya selama proses pembelajaran. Penerapan metode Brainstorming efektif untuk meningkatan kemampuan menulis teks persuasif siswa karena siswa dituntut berpikir kritis untuk mengemukakan idenya dan berpartisipasi aktif selama proses pembelajaran. Dengan demikian guru harus benar-benar memahami metode yang digunakan dan kreatif dalam memilih metode yang sesuai dengan kebutuhan. Dengan penelitian ini diharapkan dapat menjadi acuan untuk meningkatkan kualitas pembelajaran di sekolah, dan menjadi acuan berbagai mata pelajaran dengan menggunakan metode pembelajaran dalam pelaksanaannya.

\section{DAFTAR PUSTAKA}

A, Mui'in., Totok Priyadi dan Agus Wartiningsih. 2018. Peningkatan Keterampilan Menulis Teks Persuasi Menggunakan Strategi Menulis Terbimbing dan Pendekatan Pembelajaran Kontekstual. Skripsi pada FKIP Universitas Pontianak.

Dewi, Marlina Yuliantika. 2014. Penerapan Metode Pembelajaran Brainstorming Melalui Media Gambar untuk Meningkatkan Kemampuan Menulis Karangan Narasi Ekspositoris pada Siswa Kelas IV A SDN 68 Kota Bengkulu. Skripsi pada FKIP Universitas Bengkulu.

Hendriyanto, Agoes \& Nimas Permata Putri. 2014. Teori Belajar dan Pembelajaran Bahasa. Surakarta: Cakrawala Media.

Hikmat, Ade dan Nani Solihati. 2013. Bahasa Indonesia (untuk Mahasiswa S1 \& Pascasarjana, Guru, Dosen, Praktisi, dan Umum). Jakarta: Grasindo.

Juhara, erwin., Eriyandi Budiman \& Rita Rohayati. 2010. Cendekia Berbahasa: Bahasa dan Sastra Indonesia. Bandung: PT. Grafindo Media Pratama.

Kosasih, E. 2017. Bahasa Indonesia. Jakarta: Kementrian Pendidikan dan Kebudayaan.

Nurgiyantoro, Burhan. 2009. Penelitian Pengajaran Bahasa dan Sastra. Yogyakarta: BPFE.

Sudjana, Nana. 2009. Penulisan Hasil Proses Belajar Mengajar. Bandung: PT Remaja Rosdakarya. 2010. Metode dan Teknik Pembelajaran Partisipatif. Bandung: Falah Production. 
Tina, Rangga., Erizal Gani, dan Nursaid. 2013. Peningkatan Pembelajaran Menulis Argumentasi melalui Model Pembelajaran Brainstorming. Skripsi pada FBS Universitas Negeri Padang.

Wicaksono, Andri \& Ahmad Subhan Roza. 2016. Teori Pembelajaran Bahasa. Yogyakarta: Garudhawaca.

- 2014. Menulis Kreatif Sastra: dan Beberapa Model Pembelajarannya. Yogyakarta: Garudhawaca.

Yaumi, Muhammad. 2012. Pembelajaran Berbasis Multiple Intelligences. Jakarta: Dian Rakyat. 